\author{
๑Е. Ф. Чайківська
}

Лъвівсъкий національний медичний університет іл. Данила Галищького

Лъвівсъка обласна дитяча клінічна лікарня «ОХМАТДИТ»

\title{
ОСОБЛИВОСТІ ЕКСПРЕСІї ГЛОБУЛІНУ, ЯКИЙ ЗВ'ЯЗУЄ СТАТЕВІ ГОРМОНИ, У ДІВЧАТ ПУБЕРТАТНОГО ВІКУ ІЗ ДИФУЗНИМИ ЗАХВОРЮВАННЯМИ ПЕЧІНКИ
}

\begin{abstract}
Мета дослідження - оцінити особливості секреції глобуліну, який зв'язує статеві гормони (ГзСГ), у дівчат пубертатного віку із дифузними захворюваннями печінки.

Матеріали та методи. Під спостереженням перебували 582 дівчинки у віці 12-17 років, 3 яких 402 із дифузними захворюваннями гепатобіліарної системи (хронічним вірусним гепатитом ( $n=120)$, неалкогольною жировою хворобою печінки $(n=120)$, автоімунним гепатитом $(n=30)$, фріброзом та цирозом печінки $(n=12)$, дискінезією жовчних шляхів $(n=120))$ i 180 умовно соматично здорових дівчат із нормальним статевим розвитком. Після проведення комплексного гепатологічного обстеження діагноз захворювання печінки встановлював гастроентеролог. У групах із захворюваннями печінки і здорових дівчат були рівномірно представлені вікові категорії від 12 до 17 років включно. Рівень ГЗСГ у венозній крові визначали імунохімічним методом у вікових категоріях 12, 13, 14, 15, 16 і 17 років.

Результати дослідження та їх обговорення. Серед дівчаток із дифузними захворюваннями печінки у всіх вікових категоріях найбільш високий рівень ГЗСГ реєстрували у хворих на хронічний вірусний гепатит, а найменший - у дівчаток із цирозом печінки. Низькі рівні ГЗСГ були характерні також для дівчаток із неалкогольною жировою хворобою печінки. Встановлено, що продукція ГЗСг у пубертатному періоді з віком знижувалася як у соматично здорових дівчат, так і в дівчат із дифузними захворюваннями печінки. Однак, зниження продукції ГЗСГ при неалкогольній жировій хворобі та цирозі печінки було виражено більш значно, ніж у здорових дівчат. У дівчат із дискінезією жовчних шляхів вірогідних відмінностей рівнів ГЗСГ та швидкості його зниження з віком від аналогічних показників у контролі не зареєстровано.

Висновки. Рівень ГЗСГ є індикатором порушень функції печінки. ГЗСГ може бути легко вимірюваним і клінічно корисним біомаркером для раннього виявлення дітей, у яких в майбутньому можуть розвинутися хронічні дисруні захворювання печінки, а також ожиріння. Необхідні подальші дослідження, щоб зрозуміти, як регулюється ГзСГ у дітей.
\end{abstract}

Ключові слова: дівчата; пубертатний період; дифузні захворювання печінки; глобулін, який зв'язує статеві гормони.

ОСОБЕННОСТИ ЭКСПРЕССИИ ГЛОБУЛИНА, СВЯЗЫВАЮЩЕГО ПОЛОВЫЕ ГОРМОНЫ, У ДЕВОЧЕК ПУБЕРТАТНОГО ВОЗРАСТА С ДИФФУЗНЫМИ ЗАБОЛЕВАНИЯМИ ПЕЧЕНИ

Цель исследования - оценить особенности секреции глобулина, связывающего половые гормоны (ГСпГ), у девочек пубертатного возраста с диффузными заболеваниями печени.

Материалы и методы. Под наблюдением находились 582 девочки в возрасте 12-17 лет, из которых 402 с дифрфузными заболеваниями печени (хроническим вирусным гепатитом ( $\mathrm{n}=120)$, неалкогольной жировой болезнью ( $\mathrm{n}=120)$, аутоиммунным гепатитом ( $n=30)$, фиброзом и циррозом (n=12), дискинезией желчных путей $(n=120))$ и 180 условно соматически здоровых девушек с нормальным половым развитием. После проведения комплексного гепатологического обследования диагноз заболевания печени выставлялся гастроэнтерологом. В группах с заболеваниями печени и здоровых девушек были равномерно представлены возрастные категории от 12 до 17 лет включительно. Уровень ГСпГ в венозной крови определяли иммунохимическим методом в возрастных категориях 12, 13, 14, 15, 16 и 17 лет.

Результаты исследования и их обсуждение. Среди девочек с диффузными заболеваниями печени во всех возрастных категориях наиболее высокий уровень ГСПГ регистрировался у больных с хроническим вирусным гепатитом, а наименьший - у девочек с циррозом печени. Низкие уровни ГСпГ были характерны также для девочек с неалкогольной жировой болезнью печени. Установлено, что продукция ГСпг в пубертатном периоде с возрастом снижалась как у соматически здоровых девушек, так и у девушек с диффузными заболеваниями печени. Однако, снижение продукции ГСпг при неалкогольной жировой болезни и циррозе печени было выражено более значительно, чем у здоровых пациенток. У девочек с дискинезией желчных путей достоверные различия уровней ГСПГ и скорости его снижения с возрастом по сравнению с аналогичными показателями в контроле не зарегистрированы.

Выводы. Уровень ГСПГ является индикатором нарушений функции печени. ГСПГ может быть легко измеряемым и клинически полезным биомаркером для раннего выявления детей, у которых в будущем могут развиться хронические дифрфузные заболевания печени, а также ожирение. Необходимы дальнейшие исследования, чтобы понять, как регулируется Гспг у детей.

Ключевые слова: девочки; пубертатный период; диффрузные заболевания печени; глобулин, связывающий половые гормоны.

PECULIARITIES OF SEX HORMONE-BINDING GLOBULIN IN PUBERTAL GIRLS WITH DIFFUSE LIVER DISEASES

The aim of the study - to evaluate the characteristics of the secretion of sex hormone-binding globulin (SHBG) in pubertal girls with diffuse liver diseases.

Materials and Methods. The study included 582 girls aged 12-17 years, of whom 402 with diffuse liver diseases (chronic viral hepatitis $(n=120)$, non-alcoholic fatty disease $(n=120)$, autoimmune hepatitis $(n=30)$, fibrosis and cirrhosis $(n=12)$, biliary dyskinesia $(n=120)$ ) and 180 conventionally somatically healthy girls with normal sexual development. After 
a comprehensive hepatological examination, the diagnosis of liver disease was made by a gastroenterologist. In the groups with liver diseases and healthy girls, the age groups from 12 to 17, inclusive, were evenly represented. The level of SHBG in venous blood was determined by the immunochemical method in the age groups 12, 13, 14, 15, 16 and 17 years old.

Results and Discussion. Among girls with diffuse liver diseases in all age categories, the highest level of SHBG was recorded in patients with chronic viral hepatitis, and the lowest in girls with liver cirrhosis. Low SHBG levels were also characteristic of girls with non-alcoholic fatty liver disease. It was found that the production of SHBG in puberty decreased with age in both somatically healthy girls and girls with diffuse liver diseases. However, the decrease in SHBG production in non-alcoholic fatty disease and liver cirrhosis was more pronounced than in healthy patients. In girls with biliary dyskinesia, there were no significant differences in SHBG levels and the rate of its decrease with age compared with similar indicators in controls.

Conclusions. SHBG levels are an indicator of liver dysfunction. SHBG can be an easily measurable and clinically useful biomarker for the early detection of children who may develop chronic diffuse liver disease in the future as well as obesity. Further research is needed to understand how SHBG is regulated in children.

Key words: girls; puberty; diffuse liver diseases; sex hormone-binding globulin.

ВСТУП. Глобулін, який зв'язує статеві гормони (ГЗСГ), являє собою гомодимерний глікопротеїн масою 90100 кДа, який кодується одним геном на короткому плечі хромосоми 17 [1]. Циркулюючий ГЗСГ в основному продукується гепатоцитами, проте він також експресується в головному мозку, матці, простаті, грудях, яєчниках і сім'яниках, а також при деяких ракових патологіях яєчників і простати.

ГзСГ транспортує тестостерон та інші стероїди в плазмі крові, знижує швидкість їх метаболічного кліренсу і регулює їх доступ до тканин-мішеней [1]. Хоча ГЗСГ може ізолювати стероїди із тканин-мішеней, $є$ деякі свідчення того, що пов'язаний з лігандом ГЗСГ зв'язується із мембранними рецепторами і стимулює виробництво циклічного аденозинмонофросфрату [2] i/або проникає в клітини, зв'язуючись із мембранним білком мегаліном, щоб ініціювати біологічний есрект. Фізіологічне значення ГЗСГ полягає у зв'язуванні дигідротестостерону (найбільша спорідненість), тестостерону й естрадіолу (в 3 рази менша спорідненість) [3]. Зв'язані фрорми недоступні для клітин-мішеней, біологічно неактивні і $€$, свого роду, гормональним депо організму, де ГЗСг відіграє роль регулятора: приблизно 40-60 \% тестостерону пов'язані 3 ГЗСГ.

У ранньому дитинстві рівні ГЗСг відносно стабільні, але потім знижуються в період статевого дозрівання [4]. Причину цієї зміни не з' ясовано, але, ймовірно, частково це пов'язано з андрогенами, які, як відомо, пригнічують рівні ГЗСГ. Рівні ГЗСГ у дорослому віці вищі у жінок, ніж у чоловіків, що, ймовірно, пов'язано з естрадіолом, оскільки відомо, що введення естрогенів збільшує ГЗСГ [5].

Рівні ГЗСг варіюють серед людей у дуже великому діапазоні, тоді як рівень ГЗСГ у кожної окремої людини відносно постійний. Рівні ГЗСГ не пов'язані з прийманням їжі або часом дня, їх можна легко виміряти в зразку крові з пальця [6, 7].

Рівні ГЗСГ стають меншими зі збільшенням ожиріння і підвищуються із втратою маси. Низький рівень ГЗСГ є біомаркером майбутнього розвитку метаболічного синдрому [8], гестаційного діабету [9] і цукрового діабету II типу [10-12]. Рівень ГЗСГ є показником інсулінорезистентності (IP), і багато досліджень підтвердили цей результат [13]. Традиційним поясненням низького рівня ГЗСГ при IP $\epsilon$ гіперінсулінемія [14]. Експресія гена ГЗСг при цьому знижується цитокінами - фрактором некрозу пухлини- $\alpha$ (TNF $\alpha)[9,15]$ та інтерлейкіном-1 $[11,16]$.
Ядерний рецептор ядерного фрактора печінки-4а (HNF4 $\alpha$ ) активує промотори багатьох генів, які експресуються в печінці і відіграють ключову роль у метаболізмі ліпідів [17]. Функціональні сайти зв'язування HNF4a виявлені в більш ніж 140 генах, включаючи ті, які беруть участь у метаболізмі глюкози, ліпідів і амінокислот, а також в проксимальному промоторі гена ГЗСГ. Ефект TNFa на придушення експресії ГЗСГ in vitro опосередкований HNF4a [18], і існує сильна кореляція між рівнями експресії HNF4a і ГЗСГ у печінці людини [19]. Таким чином, регуляція HNF4a відіграє центральну роль у визначенні рівня ГЗСГ у плазмі.

ГЗСГ виробляється в печінці, і захворювання печінки впливають на його рівні через безліч механізмів. Рівні ГЗСГ помітно підвищуються при гепатиті В або гепатиті С. У пацієнтів із захворюванням печінки через гемохроматоз розвивається гіпогонадотропний гіпогонадизм через відкладення заліза в гіпофрізі і, як правило, рівень гЗСг трохи підвищений. Неалкогольна жирова хвороба печінки, стан підвищеного рівня тригліцеридів у печінці пов'язані зі збільшенням вісцеральної жирової тканини, IP і дисліпідемією, а також із низьким рівнем ГЗСГ [20]. Даних щодо продукції ГЗСг у дівчаток в період статевого дозрівання як у когорті соматично здорових пацієнток, так і когорті осіб із дифрузними захворюваннями печінки мало.

МЕТА ДОСЛІДЖЕННЯ - оцінити особливості секреції глобуліну, який зв'язує статеві гормони, у дівчат пубертатного віку із дифузними захворюваннями печінки.

МАТЕРІАЛИ ТА МЕТОДИ. ПіД спостереженням перебували 582 дівчинки у віці 12-17 років, з яких 402 із дифузними захворюваннями печінки: 120 пацієнток - із хронічним вірусним гепатитом групи ХВГ (за МКХ-10 - код В 18), 120 - 3 неалкогольною жировою хворобою печінки групи НЖХП (за МКХ-10 - код К 76.0), 30 - з автоімунним гепатитом групи АГ (за МКХ-10 - код К 75.4), 12 - з фіброзом та цирозом печінки групи цП (за МКХ-10 - код К 74), 120 - $з$ дискінезією жовчних шляхів групи ДЖШ (за МКХ-10 - код К 82.8.0), - і 180 умовно соматично здорових дівчат із нормальним статевим розвитком групи К.

Комплекс обстеження включав клініко-анамнестичні дані, антропометрію, оцінку статевого розвитку, клінічний аналіз крові, загальний аналіз сечі, копрограму, паразитологічне обстеження калу, електрокардіографрію, дослідження ліпідограми, рівня глюкози, інсуліну, визначення НОМА-індексу, АЛТ, АСТ, загального білка, амілази, аналіз крові на маркери гепатитів B, C (HBsAg, 
анти-HBc IgG, анти-HCV IgG сумарний, анти-HCV IgG до cor-антигену), автоімунологічні дослідження (антинуклеарні антитіла - ANA, антигладеньком'язові антитіла - SMA, антитіла до мікросом печінки та нирок - LKM 1), ультразвукове дослідження органів гепатобіліарної системи та ехохолецистограсрію за стандартними методиками, консультацію ендокринолога, гастроентеролога, за показаннями - кардіолога, пульмонолога, алерголога та інших фрахівців. Спеціальний комплекс діагностичних методів включав панель неінвазивних методів оцінки стану печінки - тест ФіброМакс, ФіброТест, ГеноФіброТест. Діагноз захворювань гепатобіліарної системи встановлював гастроентеролог.

Рівень ГЗСГ у венозній крові визначали імунохімічним методом $з$ електрохемілюмінесцентною детекцією за допомогою тест-систем Roche Diagnostics (Швейцарія) на аналізаторі Cobas 6000 відповідно до інструкцій виробника.

Статистичний аналіз результатів проводили за допомогою пакета Statistica 10.0 for Windows. Використовували пакет статистичних програм Excel 2010 для організації та фрормування матриці даних, підготовки графріків і діаграм. Кількісні змінні описані за допомогою середнього значення (М), похибки стандартного відхилення (SE), а їх порівняння з використанням t-критерію Стьюдента.

РЕЗУЛЬТАТИ ДОСЛІДЖЕННЯ ТА ЇХ ОБГОВОРЕННЯ. Середній вік дівчат досліджуваних груп не мав вірогідної різниці і в контрольній групі К склав $(14,50 \pm 0,13)$ року, групі 3 хронічним вірусним гепатитом - $(14,50 \pm 0,16)$ року, з неалкогольною жировою хворобою печінки - $(14,50 \pm 0,16)$ року, з автоімунним гепатитом - $(14,50 \pm 0,32)$ року, з цирозом печінки - $(14,50 \pm 0,54)$ року, з дискінезією жовчних шляхів - $(14,50 \pm 0,16)$ року. При проведенні дослідження набір дівчат у групи був проведений рівномірно у вікові категорії 11, 12, 13, 14, 15, 16 і 17 років (табл. 1).

Це дало змогу оцінити динаміку секреції ГЗСГ впродовж статевого розвитку дівчат (табл. 2).

У всіх групах відмічено зниження секреції гзСг із віком.

У дівчат групи К із віком спостерігали зниження секреції ГЗСГ за експоненціальною залежністю $\mathrm{y}=-9,515 \ln (\mathrm{x})+$ 74,439 , де x - кількість років (рис. 1).

Таблиця 1. Віковий розподіл дівчат у групах, $\mathbf{n}$

\begin{tabular}{|l|c|c|c|c|c|c||}
\hline \multirow{2}{*}{ Група } & \multicolumn{6}{c||}{ Кількість дівчаток у віковій категорії } \\
\cline { 2 - 7 } & 12 років & 13 років & 14 років & 15 років & 16 років & 17 років \\
\hline К, $\mathrm{n}=180$ & 30 & 30 & 30 & 30 & 30 & 30 \\
\hline $\mathrm{XВГ,} \mathrm{n}=120$ & 20 & 20 & 20 & 20 & 20 & 20 \\
\hline $\mathrm{HЖXП,} \mathrm{n}=120$ & 20 & 20 & 20 & 20 & 20 & 20 \\
\hline $\mathrm{A} \Gamma, \mathrm{n}=30$ & 5 & 5 & 5 & 5 & 5 & 5 \\
\hline ЦП, $\mathrm{n}=12$ & 2 & 2 & 2 & 2 & 2 & 2 \\
\hline ДЖШ, $\mathrm{n}=120$ & 20 & 20 & 20 & 20 & 20 & 20 \\
\hline \hline
\end{tabular}

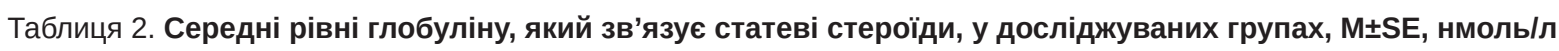

\begin{tabular}{|c|c|c|c|c|c|c|}
\hline Група & 12 років & 13 років & 14 років & 15 років & 16 років & 17 років \\
\hline$K, n=180$ & $74,23 \pm 6,60$ & $67,87 \pm 5,46$ & $64,43 \pm 6,63$ & $61,40 \pm 4,88$ & $58,97 \pm 6,52$ & $57,13 \pm 7,07$ \\
\hline $\mathrm{XB} \Gamma, \mathrm{n}=120$ & $8,80 \pm 8,16^{\mathrm{k}, 2,3,4}$ & $75,45 \pm 7,38^{\mathrm{k}, 2,3,4}$ & $74,35 \pm 8,63^{\kappa, 2,3,4}$ & $0,25 \pm 6,78^{\mathrm{k}, 2,3,4,5}$ & $69,45 \pm 9,00^{k, 2,3,4}$ & $01^{\mathrm{k}, 2,3,4}$ \\
\hline НЖХП, n=120 & $4,45 \pm 4,75^{\kappa, 1,3,4,5}$ & $7^{\mathrm{K}, 1,3,4,5}$ & $35,70 \pm 4,72^{\mathrm{k}, 1,3,4,5}$ & $32,45 \pm 4,24^{\kappa, 1,3,4,5}$ & $29,85 \pm 3,84^{\mathrm{k}, 1,3,4,5}$ & $28,65 \pm 3,40^{\mathrm{k}, 1,3,4,5}$ \\
\hline $\mathrm{A} \Gamma, \mathrm{n}=30$ & $1,60 \pm 10,46^{\kappa, 1,2,4,5}$ & $57,00 \pm 5,71^{\kappa, 1,2,4,5}$ & $55,40 \pm 4,97^{\mathrm{k}, 1,2,4,5}$ & $51,80 \pm 6,79^{\kappa, 1,2,4,5}$ & $48,60 \pm 5,30^{\kappa, 1,2,4,5}$ & $32,60 \pm 4,30^{\kappa, 1,2,4,5}$ \\
\hline ЦП, n=12 & $51,50 \pm 4,95^{\kappa, 1,2,3,5}$ & $35,00 \pm 8,49^{k, 1,2,3,5}$ & $32,00 \pm 9,90^{\kappa, 1,2,3,5}$ & $28,50 \pm 6,36^{\mathrm{k}, 1,2,3,5}$ & $25,50 \pm 3,50^{\kappa, 1,2,3,5}$ & $23,50 \pm 6,36^{\mathrm{k}, 1,2,3,5}$ \\
\hline ДЖШ, n=120 & $73,80 \pm 8,16^{\kappa, 1,2,3,4}$ & $66,15 \pm 7,43^{k, 1,2,3,4}$ & $69,35 \pm 8,63^{k, 1,2,3,4}$ & $62,25 \pm 6,78^{\mathrm{k}, 1,2,3,4}$ & $60,00 \pm 9,28^{\mathrm{k}, 1,2,3,4}$ & $54,95 \pm 5,51^{k, 1,2,3,4}$ \\
\hline
\end{tabular}

Примітка. к,1, 2, 3,4,5 - статистично значима різниця з аналогічними показниками груп К, ХВГ, НЖХП, АГ, ЦП, ДЖШ (р<0,05).



Рис. 1. Динаміка секреції гзСг у здорових дівчаток. 
ГЗСГ може функціонувати в дитинстві, обмежуючи дію статевих стероїдів до статевого дозрівання, коли рівні статевих стероїдів підвищуються разом з падінням рівнів ГЗСГ у плазмі, так що загальний результат - прогресивне збільшення як загального, так і вільного рівнів статевих гормонів. Механізм зниження ГЗСг у період статевого дозрівання не зовсім зрозумілий, але, мабуть, є скоріше метаболічним, ніж гормональним, оскільки зниження відбувається у хлопчиків з гіпопітуїтаризмом [5]. Більш того, на початок нормального статевого дозрівання знижується чутливість до інсуліну [21], що також може привести до зниження рівня ГЗСГ.

Як видно 3 таблиці 2 та рисунка 2, у групах дівчаток із дифузними захворюваннями печінки також відмічено зниження секреції ГЗСГ із віком.

Серед дівчаток із дифузними захворюваннями печінки найнижчі рівні ГЗСГ спостерігали в групах з неалкогольною жировою хворобою та цирозом печінки (див. табл. 2 і рис. 2), у групі з хронічним вірусним гепатитом відмічали підвищення рівнів ГЗСГ, тоді як у дівчаток із дискінезією жовчних шляхів вірогідних відмінностей від аналогічних рівнів ГЗСГ у контрольній групі не зареєстровано.

Отримані дані збігаються з результатами інших досліджень. Печінковий жир пов'язаний з IP, і недавні дослідження пов'язали стеатоз печінки з низьким рівнем ГЗСГ. Кількість жиру в печінці є найсильнішим предиктором низького рівня ГЗСГ [22]. Кілька досліджень виявили сильну зворотну кореляцію між кількістю жиру в печінці і рівнями ГЗСГ у сироватці крові $[20,23]$, причому, якщо рівні ГЗСГ підвищуються, жир у печінці зменшується із втратою маси [24]. Існує думка, що зниження рівнів ГЗСГ під час статевого дозрівання пов'язано зі збільшенням жирової маси у дітей та підлітків [25].

Дитяче ожиріння є однією з найбільш серйозних проблем зі здоров'ям на сьогодні через його високу поширеність і пов'язаність із багатьма хронічними захворюваннями та коротшою тривалістю життя [26, 27]. J. Pinkney et al. (2014) [28] встановили, що дівчатка 3 більш низьким рівнем ГЗСГ у 5-річному віці досягли стадії
2 по Таннеру раніше, мали тенденцію до більш раннього збільшення секреції лютеїнізуючого гормону і більш раннього віку з максимальною швидкістю росту й менархе. Автори повідомили про негативну кореляцію між ГЗСГ й ожирінням, рівнем інсуліну, інсуліноподібного фрактора росту-І, С-реактивним протеїном і лептином, а також про позитивний зв'язок між адипонектином і ГЗСг [4].

Неалкогольна жирова хвороба печінки стала найбільш частою фрормою захворювання печінки в дитинстві [24]. Було показано, що рівні ГЗСГ підвищуються в міру зменшення жиру в печінці із втратою маси. У світлі цих результатів ГЗСГ є альтернативним маркером стратифрікації ризику неалкогольної жирової хвороби печінки у дітей, а в деяких дітей із підвищеним ризиком неалкогольної жирової хвороби печінки і метаболічного синдрому може бути корисним біомаркером, можливо, щодо розвитку ожиріння.

Накопичуються дані про те, що статеве дозрівання у дівчаток настає в більш ранньому віці, й епідемія ожиріння $€$ важливим фрактором у цьому явищі [21]. У дослідженні 132 здорових дітей та підлітків європеоїдної раси ГЗСГ був сильним предиктором чутливості до інсуліну після поправки на статеве дозрівання і жирову масу [29].

Недавні дослідження виявили тривожне зростання показників підліткового ожиріння і таких супутніх захворювань, як цукровий діабет другого типу, метаболічний синдром, перипубертатна гіперандрогенемія, синдром полікістозних яєчників (СПКЯ), неалкогольна жирова хвороба печінки і раннє статеве дозрівання $[8,13,27$, 30-36]. Ці асоціації можна пояснити тим, що низький рівень ГЗСГ є маркером IP, етіологія і патогенез перерахованих захворювань багатофакторні, вони контролюються генетичними фракторами, внутрішньоутробним середовищем і нездоровим способом життя [30]. Дочки-підлітки пацієнток із СПкя з більшою ймовірністю мають ознаки метаболічного синдрому і гіперінсулінемію [37], великі яєчники, починаючи зі стадії 1 по Таннеру, а при стадії $\checkmark$ по Таннеру мають більш низькі рівні ГЗСГ, ніж дочки, народжені від жінок контрольної групи [38].

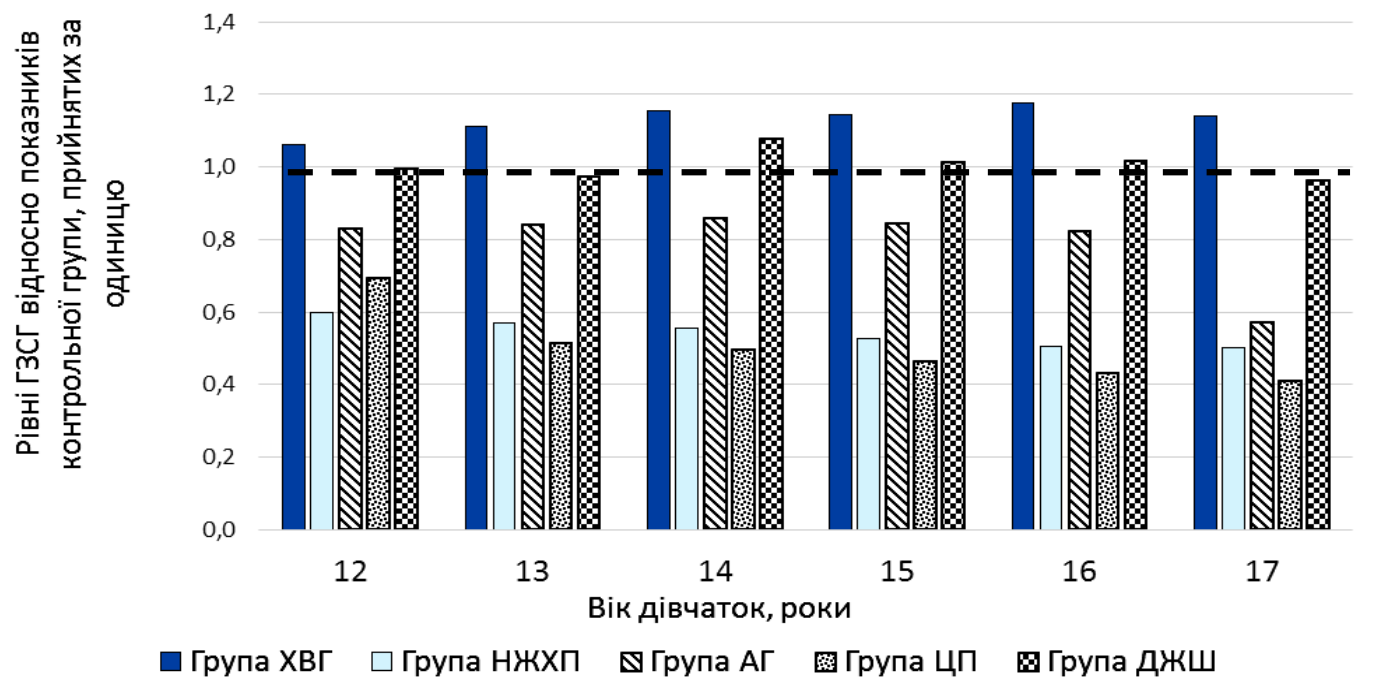

Рис. 2. Рівні ГзСг у дівчат пубертатного віку з дисузними захворюваннями печінки відносно показників контрольної групи, прийнятих за одиницю.

Примітка. - - - - рівень ГЗСГ у групі контролю у відповідній віковій категорії, прийнятий за одиницю. 
Рівні ГЗСг можуть бути низькими у здорових та повних дівчат у перипубертатному періоді, а втрата маси може бути пов'язана зі зниженням рівня тестостерону і збільшенням рівнів ГзСг $[7,39]$. Однак не всі дівчатка 3 перипубертатним ожирінням мають підвищений рівень андрогенів, і не всі підлітки з гіперандрогенією страждають від ожиріння або надлишкової маси тіла, що дозволяє припустити, що ожиріння, як такого, недостатньо для зниження ГЗСГ та розвитку перипубертатної гіперандрогенії [28].

ВИСНОВКИ. Продукція ГЗСг у пубертатному періоді з віком знижується як у соматично здорових дівчат, так і в дівчат із дифузними захворюваннями печінки. Однак, зниження продукції ГЗСГ при неалкогольній жировій хворобі та цирозі печінки виражено більш значно, ніж у здорових дівчат. У дівчат-підлітків із дискінезією жовчних шляхів вірогідних відмінностей рівнів ГЗСГ від аналогічних рівнів у контролі не зареєстровано. Низький рівень ГЗСГ $є$ індикатором порушень функції печінки. ГЗСГ може бути легко вимірюваним і клінічно корисним біомаркером для раннього виявлення дітей, у яких в майбутньому можуть розвинутися хронічні дифузні захворювання печінки, а також ожиріння.

ПЕРСПЕКТИВИ ПОДАЛЬШИХ ДОСЛІДЖЕНЬ. НЕОбхідні подальші дослідження, щоб зрозуміти, як регулюється ГЗСГ у дітей. Зрештою, ще необхідно з'ясувати, чи $€$ ГЗСГ виключно біомаркером, чи, імовірніше, активно бере участь у патогенезі метаболічних захворювань.

\section{СПИСОК ЛІТЕРАТУРИ}

1. Hammond G. L. Plasma steroid-binding proteins: primary gatekeepers of steroid hormone action / G. L. Hammond // J. Endocrinol. - 2016. - Vol. 230 (1). - P. 13-25.

2. Sex hormone-binding globulin and lipid profile in pubertal children / C. Garcés, I. Oya, M. A. Lasunción [et al.] // Metabolism. - 2010. - Vol. 59 (2). - P. 166-171.

3. Common genetic variants in the sex hormone-binding globulin (SHBG) gene in idiopathic recurrent pregnancy loss: a case control study / M. Dendana, R. R. Finan, M. Al-Mutawa [et al.] // Transl. Med. Commun. - 2018. - Vol. 3. - P. 5.

4. Adiposity, chronic inflammation, and the prepubertal decline of sex hormone binding globulin in children: evidence for associations with the timing of puberty (Earlybird 58) / J. Pinkney, A. Streeter, J. Hosking [et al.] // J. Clin. Endocrinol. Metab. - 2014. - Vol. 99. - P. 3224-3232.

5. Sex hormone-binding globulin and lipid profile in pubertal children / C. Garcés, I. Oya, M. A. Lasunción [et al.] // Metabolism. - 2010. - Vol. 59 (2). - P. 166-171.

6. Aydın B. Sex hormone-binding globulin in children and adolescents / B. Aydın, S. J. Winters // J. Clin. Res. Pediatr. Endocrinol. - 2016. - Vol. 8 (1). - P. 1-12.

7. Diet, physical activity and behavioural interventions for the treatment of overweight or obese adolescents aged 12 to 17 years / E. Mead, T. Brown, K. Rees [et al.] // Cochrane Database Syst. Rev. - 2017. - Vol. 6 (6). - CD012691.

8. Prevalence of prediabetes and type 2 diabetes in children with obesity and increased transaminases in European Germanspeaking countries. Analysis of the APV initiative / F. Koutny, D. Weghuber, E. Bollow [et al.] // Pediatr. Obes. - 2020. Vol. 15 (4). - P. 12601.

9. Sex hormone binding globulin as a valuable biochemical marker in predicting gestational diabetes mellitus / M. A. Tawfeek, E. M. Alfadhli, A. M. Alayoubi [et al.] // BMC. Womens Health. 2017. - Vol. 17 (1). - P. 18.

10. Associations of steroid sex hormones and sex hormonebinding globulin with the risk of type 2 diabetes in women: a population-based cohort study and meta-analysis / T. Muka, J. Nano, L. Jaspers [et al.] // Diabetes. - 2017. - Vol. 66 (3). P. 577-586.

11. Non-alcoholic fatty liver disease is an influencing factor for the association of SHBG with metabolic syndrome in diabetes patients / X. Hua, M. Li, F. Pan [et al.] // Sci. Rep. - 2017. Vol. 7(1). - P. 14532.

12. Sex hormone-binding globulin and risk of type 2 diabetes in women and men / E. L. Ding, Y. Song, J. E. Manson [et al.] // N. Engl. J. Med. - 2009. - Vol. 361 (12). - P. 1152-1163.

13. Sex hormone binding globulin and insulin resistance /
I. R. Wallace, M. C. McKinley, P. M. Bell, S. J. Hunter // Clin. Endocrinol. (Oxf). - 2013. - Vol. 78 (3). - P. 321-329.

14. Alinezhad $A$. The relationship between components of metabolic syndrome and plasma level of sex hormone-binding globulin / A. Alinezhad, F. Jafari // Eur. J. Transl. Myol. - 2019. - Vol. 29 (2). - P. 8196.

15. Potential role of tumor necrosis factor- $\alpha$ in downregulating sex hormone-binding globulin / R. Simó, A. Barbosa-Desongles, A. Lecube [et al.] // Diabetes. - 2012. - Vol. 61 (2). - P. 372-382.

16. IL1 $\beta$ down-regulation of sex hormone-binding globulin production by decreasing HNF-4 $\alpha$ via MEK-1/2 and JNK MAPK pathways / R. Simó, A. Barbosa-Desongles, C. Hernandez, D. M. Selva // Mol. Endocrinol. -2012. - Vol. 26 (11). - P. 1917-1927.

17. The hepatic lipidome and HNF4 $\alpha$ and SHBG expression in human liver / S. J. Winters, C. R. Scoggins, D. Appiah, D. T. Ghooray // Endocr. Connect. - 2020. - Vol. 9 (10). P. 1009-1018.

18. Molecular Mechanism of TNFa-induced down-regulation of SHBG expression / R. Simó, A. Barbosa-Desongles, C. SáezLopez [et al.]// Mol. Endocrinol. -2012. - Vol. 26 (3). - P. 438-446.

19. Sex hormone-binding globulin gene expression and insulin resistance / S. J. Winters, J. Gogineni, M. Karegar [et al.] // J. Clin. Endocrinol. Metab. - 2014. - Vol. 99 (12). - P. 2780-2788.

20. Low serum sex hormon Onset of breast development in a longitudinal cohort / F. M. Biro, L. C. Greenspan, M. P. Galvez [et al.] // Pediatrics. - 2013. - Vol. 132. - P. 1019-1027.

21. e-binding globulin is associated with nonalcoholic fatty liver disease in type 2 diabetic patients / X. Hua, Y. Sun, Y. Zhong [et al.] // Clin. Endocrinol. (Oxf). - 2014. - Vol. 80 (6). - P. 877-883.

22. Longitudinal associations between sex hormone-binding globulin and insulin resistance / K. Ottarsdottir, M. Hellgren, D. Bock [et al.] // Endocr. Connect. - 2020. - Vol. 9 (5). - P. 418-425.

23. Association between endogenous sex hormones and liver fat in a multiethnic study of atherosclerosis / M. Lazo, I. Zeb, K. Nasir [et al.] // Clin. Gastroenterol. Hepatol. - 2015. - Vol. 13 (9). - P. 1686-1693.

24. Stefan N. Sex hormone-binding globulin and risk of type 2 diabetes / N. Stefan, F. Schick, H. U. Häring // N. Engl. J. Med. - 2009. - Vol. 361 (27). - P. - 2675-2676.

25. Insulin resistance and bone age advancement in girls with central precocious puberty / J. H. Hur, S. Park, M. K. Jung [et al.] // Ann. Pediatr. Endocrinol. Metab. - 2017. - Vol. 22 (3). - P. 176-182.

26. Marcovecchio M. L. Metabolic syndrome in youth: chimera or useful concept? / M. L. Marcovecchio, F. Chiarelli // Curr. Diab. Rep. - 2013. - Vol. 13 (1). - P. 56-62. 
27. Morandi A. Predictors of metabolic risk in childhood obesity / A. Morandi, C. Maffeis // Horm. Res. Paediatr. - 2014. - Vol. 82 (1). - P. 3-11.

28. Hyperandrogenemia in obese peripubertal girls: correlates and potential etiological determinants / K. L. Knudsen, S. K. Blank, C. Burt Solorzano [et al.] // Obesity (Silver Spring). - 2010. - Vol. 18 (11). - P. 2118-2124.

29. Sex hormone-binding globulin levels predict insulin sensitivity, disposition index, and cardiovascular risk during puberty / K. Sørensen, L. Aksglaede, T. Munch-Andersen [et al.] // Diabetes Care. - 2009. - Vol. 32 (5). - P. 909-914.

30. A guide to non-alcoholic fatty liver disease in childhood and adolescence // J. L. Temple, P. Cordero, J. Li [et al.] // Int. J. Mol. Sci. - 2016. - Vol. 17 (6). - P. 947.

31. A reappraisal of testosterone's binding in circulation: physiological and clinical implications / A. L. Goldman, S. Bhasin, F. C. W. Wu [et al.] // Endocr. Rev. - 2017. - Vol. 38 (4). P. 302-324.

32. Association of prepubertal obesity with pubertal development in chinese girls and boys: A longitudinal study / W. Li, Q. Liu, X. Deng [et al.] // Am. J. Hum. Biol. - 2018. Vol. 30 (6). - P. 23195.

33. Dadachanji R. Genetic variants associated with hyperandrogenemia in PCOS pathophysiology / R. Dadachanji, N. Shaikh, S. Mukherjee // Genet. Res. Int. - 2018. - Vol. 2018. - P. 7624932.

\section{REFERENCES}

1. Hammond, G.L. (2016). Plasma steroid-binding proteins: primary gatekeepers of steroid hormone action. J. Endocrinol., 230 (1), R13-R25. DOI:10.1530/JOE-16-0070.

2. Garcés, C., Oya, I.D., Lasunción, M.A., López-Simón, L., Cano, B., \& de Oya, M. (2010). Sex hormone-binding globulin and lipid profile in pubertal children. Metab. Clin. Exp., 59 (2), 166-171. DOI:10.1016/j.metabol.2009.06.033.

3. Dendana, M., Finan, R.R., Al-Mutawa, M., \&Almawi, W.Y. (2018). Common genetic variants in the sex hormone-binding globulin (SHBG) gene in idiopathic recurrent pregnancy loss: a case control study. Transl. Med. Commun., 3 (1), 5. DOI:10.1186/ s41231-018-0024-1.

4. Pinkney, J., Streeter, A., Hosking, J., Mostazir, M., Jeffery, A., \& Wilkin, T. (2014). Adiposity, chronic inflammation, and the prepubertal decline of sex hormone binding globulin in children: evidence for associations with the timing of puberty (Earlybird 58). J. Clin. Endocrin. Metab., 99 (9), 3224-3232. DOI:10.1210/ jc.2013-3902.

5. Garcés, C., Oya, I.D., Lasunción, M.A., López-Simón, L., Cano, B., \& de Oya, M. (2010). Sex hormone-binding globulin and lipid profile in pubertal children. Metab. Clin. Exp., 59 (2), 166-171. DOI:10.1016/j.metabol.2009.06.033.

6. Aydın, B., \& Winters, S.J. (2016). Sex hormone-binding globulin in children and adolescents. J. Clin. Res. Pediatr. Endocrinol., 8 (1), 1-12. DOI:10.4274/jcrpe.2764.

7. Mead, E., Brown, T., Rees, K., Azevedo, L.B., Whittaker, V., Jones, D., ..., \& Ells, L.J. (2017). Diet, physical activity and behavioural interventions for the treatment of overweight or obese children from the age of 6 to 11 years. Cochrane Database Syst. Rev., 6 (6), CD012651. DOI:https://doi.org/10.1002/14651858.CD012651.

8. Koutny, F., Weghuber, D., Bollow, E., Greber-Platzer, S., Hartmann, K., Körner, A., ..., \& Holl, R.W. (2020). Prevalence of prediabetes and type 2 diabetes in children with obesity and increased transaminases in European German-speaking countries. Analysis of the APV initiative. Pediatr. Obes., 15 (4), e12601. DOI:10.1111/ijpo.12601.
34. Rosenfield R. L. The diagnosis of polycystic ovary syndrome in adolescents / R. L. Rosenfield // Pediatrics. - 2015. - Vol. 136 (6). - P. 1154-1165.

35. Sex hormone-binding globulin, oligomenorrhea, polycystic ovary syndrome, and childhood insulin at age 14 years predict metabolic syndrome and class III obesity at age 24 years / C. J. Glueck, J. A. Morrison, S. Daniels [et al.] // J. Pediatr. - 2011. - Vol. 159 (2). - P. 308-313.

36. Witchel S. F. Polycystic ovary syndrome: pathophysiology, presentation, and treatment with emphasis on adolescent girls / S. F. Witchel, S. E. Oberfield, A. S. Peña // J. Endocr. Soc. 2019. - Vol. 3 (8). - P. 1545-1573.

37. Hyperandrogenism and hyperinsulinism in children of women with polycystic ovary syndrome: a controlled study I S. C. Kent, C. L. Gnatuk, A. R. Kunselman [et al.] // J. Clin. Endocrinol. Metab. - 2008. - Vol. 93 (5). - P. 1662-1669.

38. Relationship between anti-Müllerian hormone $(\mathrm{AMH})$ and insulin levels during different tanner stages in daughters of women with polycystic ovary syndrome / T. Sir-Petermann, A. Ladrón de Guevara, E. Codner [et al.] // Reprod. Sci. - 2012. - Vol. 19 (4). - P. 383-390.

39. Sex difference determined the role of sex hormonebinding globulin in obese children during short-term weight reduction program / F. M. Wang, C. M. Lin, S. H. Lien [et al.] // Medicine (Baltimore). - 2017. - Vol. 96 (19). - P. e6834.

9. Tawfeek, M.A., Alfadhli, E.M., Alayoubi, A.M., ElBeshbishy, H.A., \& Habib, F.A. (2017). Sex hormone binding globulin as a valuable biochemical marker in predicting gestational diabetes mellitus. BMC. Women's Health, 17 (1), 18. DOI:10.1186/s12905-017-0373-3.

10. Muka, T., Nano, J., Jaspers, L., Meun, C., Bramer, W.M., Hofman, A., ..., \& Franco, O.H. (2017). Associations of steroid sex hormones and sex hormone-binding globulin with the risk of type 2 diabetes in women: a population-based cohort study and meta-analysis. Diabetes, 66 (3), 577-586. DOI:10.2337/ db16-0473.

11. Hua, X., Li, M., Pan, F., Xiao, Y., Cui, W., \& Hu, Y. (2017). Non-alcoholic fatty liver disease is an influencing factor for the association of SHBG with metabolic syndrome in diabetes patients. Sci. Rep., 7 (1), 14532. DOI:10.1038/s41598-01715232-9.

12. Ding, E.L., Song, Y., Manson, J.E., Hunter, D.J., Lee, C.C., Rifai, N., ..., \& Liu, S. (2009). Sex hormone-binding globulin and risk of type 2 diabetes in women and men. N. Engl. J. Med., 361 (12), 1152-1163. DOI:10.1056/NEJMoa0804381.

13. Wallace, I.R., McKinley, M.C., Bell, P.M., \& Hunter, S.J. (2013). Sex hormone binding globulin and insulin resistance. Clin. Endocrinol., 78 (3), 321-329. DOI:10.1111/cen.12086.

14. Alinezhad, A., \& Jafari, F. (2019). The relationship between components of metabolic syndrome and plasma level of sex hormone-binding globulin. Eur. J. Transl. Myol., 29 (2), 8196. DOI:10.4081/ejtm.2019.8196.

15. Simó, R., Barbosa-Desongles, A., Lecube, A., Hernandez, C., \& Selva, D.M. (2012). Potential role of tumor necrosis factor- $\alpha$ in downregulating sex hormone-binding globulin. Diabetes, 61 (2), 372-382. DOI:10.2337/db11-0727.

16. Simó, R., Barbosa-Desongles, A., Hernandez, C., \& Selva, D.M. (2012). IL1 $\beta$ down-regulation of sex hormonebinding globulin production by decreasing HNF-4 $\alpha$ via MEK-1/2 and JNK MAPK pathways. Mol. Endocrinol. (Baltimore, Md.), 26 (11), 1917-1927. DOI:10.1210/me.2012-1152. 
17. Winters, S.J., Scoggins, C.R., Appiah, D., \& Ghooray, D.T. (2020). The hepatic lipidome and HNF4 $\alpha$ and SHBG expression in human liver. Endocr. Connect., 9 (10), 1009-1018. DOI:10.1530/EC-20-0401.

18. Simó, R., Barbosa-Desongles, A., Sáez-Lopez, C., Lecube, A., Hernandez, C., \& Selva, D.M. (2012). Molecular Mechanism of TNF $\alpha$-Induced Down-Regulation of SHBG Expression. Mol. Endocrinol. (Baltimore, Md.), 26 (3), 438-446. DOI:10.1210/me.2011-1321.

19. Winters, S.J., Gogineni, J., Karegar, M., Scoggins, C., Wunderlich, C.A., Baumgartner, R., \& Ghooray, D.T. (2014). Sex hormone-binding globulin gene expression and insulin resistance. J. Clin. Endocrinol. Metab., 99 (12), E2780-E2788. DOI:10.1210/jc.2014-2640.

20. Hua, X., Sun, Y., Zhong, Y., Feng, W., Huang, H., Wang, W., ..., \& Hu, Y. (2014). Low serum sex hormone-binding globulin is associated with nonalcoholic fatty liver disease in type 2 diabetic patients. Clin. Endocrinol., 80 (6), 877-883. DOI:10.1111/ cen.12360.

21. Biro, F.M., Greenspan, L.C., Galvez, M.P., Pinney, S.M., Teitelbaum, S., Windham, ..., \& Wolff, M.S. (2013). Onset of breast development in a longitudinal cohort. Pediatrics, 132 (6), 1019-1027. DOI:10.1542/peds.2012-3773.

22. Ottarsdottir, K., Hellgren, M., Bock, D., Nilsson, A.G., \& Daka, B. (2020). Longitudinal associations between sex hormone-binding globulin and insulin resistance. Endocr. Connect., 9 (5), 418-425. DOI:10.1530/EC-20-0141.

23. Lazo, M., Zeb, I., Nasir, K., Tracy, R. P., Budoff, M. J., Ouyang, P., \& Vaidya, D. (2015). Association between endogenous sex hormones and liver fat in a multiethnic study of atherosclerosis. Clin. Gastroenterol. Hepatol., 13 (9), 1686-93. e2. DOI:10.1016/j.cgh.2014.12.033.

24. Stefan, N., Schick, F., \& Häring, H.U. (2009). Sex hormone-binding globulin and risk of type 2 diabetes. N. Engl. J. Med., 361 (27), 2675-2678. DOI:10.1056/NEJMc0910143.

25. Hur, J.H., Park, S., Jung, M.K., Kang, S.J., Kwon, A., Chae, H.W., ..., \& Kim, D.H. (2017). Insulin resistance and bone age advancement in girls with central precocious puberty. Ann. Pediatr. Endocrinol. Metab., 22 (3), 176-182. DOI:10.6065/ apem.2017.22.3.176.

26. Marcovecchio, M.L., \& Chiarelli, F. (2013). Metabolic syndrome in youth: chimera or useful concept? Curr. Diabetes Rep., 13 (1), 56-62. DOI:10.1007/s11892-012-0331-2.

27. Morandi, A., \& Maffeis, C. (2014). Predictors of metabolic risk in childhood obesity. Horm. Res. Paediatr., 82 (1), 3-11. DOI:10.1159/000362237.

28. Knudsen, K.L., Blank, S.K., Burt Solorzano, C., Patrie, J.T. Chang, R.J., Caprio, S., ..., \& McCartney, C.R. (2010). Hyperandrogenemia in obese peripubertal girls: correlates and potential etiological determinants. Obes. (Silver Spring, Md.), 18 (11), 2118-2124. DOI:10.1038/oby.2010.58.
29. Sørensen, K., Aksglaede, L., Munch-Andersen, T., Aachmann-Andersen, N.J., Petersen, J.H., Hilsted, L., ..., \& Juul, A. (2009). Sex hormone-binding globulin levels predict insulin sensitivity, disposition index, and cardiovascular risk during puberty. Diabetes Care, 32 (5), 909-914. DOI:10.2337/ dc08-1618.

30. Temple, J.L., Cordero, P., Li, J., Nguyen, V., \& Oben, J.A. (2016). A guide to non-alcoholic fatty liver disease in childhood and adolescence. Int. J. Mol. Sci., 17 (6), 947. DOI:10.3390/ ijms17060947.

31. Goldman, A.L., Bhasin, S., Wu, F., Krishna, M., Matsumoto, A.M., \& Jasuja, R. (2017). A reappraisal of testosterone's binding in circulation: physiological and clinical implications. Endocr. Rev., 38 (4), 302-324. DOI:10.1210/er.2017-00025.

32. Li, W., Liu, Q., Deng, X., Chen, Y., Yang, B., Huang, X., \& Østbye, T. (2018). Association of prepubertal obesity with pubertal development in Chinese girls and boys: A longitudinal study. Am. J. Hum. Biol., 30 (6), e23195. DOl:10.1002/ ajhb.23195.

33. Dadachanji, R., Shaikh, N., Mukherjee, S. (2018). Genetic variants associated with hyperandrogenemia in PCOS pathophysiology. Genet. Res. Int., 18, 7624932. DOI:10.1155/2018/7624932.

34. Rosenfield, R.L. (2015). The diagnosis of polycystic ovary syndrome in adolescents. Pediatrics, 136 (6), 1154-1165. DOI:10.1542/peds.2015-1430.

35. Glueck, C.J., Morrison, J.A., Daniels, S., Wang, P., \& Stroop, D. (2011). Sex hormone-binding globulin, oligomenorrhea, polycystic ovary syndrome, and childhood insulin at age 14 years predict metabolic syndrome and class III obesity at age 24 years. J. Pediatr., 159 (2), 308-313.e2. DOI:10.1016/j. jpeds.2011.01.018.

36. Witchel, S.F., Oberfield, S.E., \& Peña, A.S. (2019). Polycystic ovary syndrome: pathophysiology, presentation, and treatment with emphasis on adolescent girls. J. Endocr. Soc., 3 (8), 1545-1573. DOI:10.1210/js.2019-00078.

37. Kent, S.C., Gnatuk, C.L., Kunselman, A.R., Demers, L.M. Lee, P.A., \& Legro, R.S. (2008). Hyperandrogenism and hyperinsulinism in children of women with polycystic ovary syndrome: a controlled study. J. Clin. Endocrinol. Metab., 93 (5), 1662-1669. DOI:10.1210/jc.2007-1958.

38. Sir-Petermann, T., Ladrón de Guevara, A., Codner, E., Preisler, J., Crisosto, N., Echiburú, B., ..., \& Cassorla, F. (2012). Relationship between anti-Müllerian hormone $(\mathrm{AMH})$ and insulin levels during different tanner stages in daughters of women with polycystic ovary syndrome. Reprod. Sci. (Thousand Oaks, Calif.), 19 (4), 383-390. DOI:10.1177/1933719111424444.

39. Wang, F.M., Lin, C.M., Lien, S.H., Wu, L.W., Huang, C.F., \& Chu, D.M. (2017). Sex difference determined the role of sex hormone-binding globulin in obese children during shortterm weight reduction program. Medicine, 96 (19), e6834. DOI:10.1097/MD.0000000000006834

Отримано 26.08.20 Прийнято до друку 30.09.20

Електронна адреса для листування: elinachaykivska@gmail.com 